\title{
Institutional Repositories: Facilitating Structure, Collaborations, Scholarly Communications, and Institutional Visibility
}

\author{
Liauw Toong Tjiek (Aditya Nugraha) \\ Petra Christian University \\ Indonesia
}

\section{Introduction}

The advancement of information and communication technology (ICT) - Internet in particular - has caused enormous changes in the world we are living today. Many things are not what they used to be decades, or even years ago. Imagine how we communicated and shared information in the fifties, when computers were still 'archaic' and the Internet was still in its inception stage. Compare that to the numerous communication gadgets and the information overload that we have today. All those changes happened in only a little over fifty years.

Libraries as information providers have also undergone massive changes due to their close association to the way people communicate, collect, manage, use, and share information. Any advancement in ICT will have direct and indirect impacts on the ways libraries provide their collections and services to their user communities and society in general. Some advancements might be welcome by libraries. Others might be perceived as threats to the existence of (traditional) libraries since they are perceived as 'things' that would cause (traditional) libraries to become obsolete, or at least redundant, amidst the new emerging technologies. Some have also caused mixed reactions among librarians, who might 'love' and 'hate' them at the same time. Librarians usually love advancements in ICT since they can help tremendously in the librarians' efforts to fulfill the information needs of their users. However librarians might also notice that many (or most?) of their traditional roles as librarians have been, or will be, taken away from them by those advancements.

Digital libraries (DLs), which include all of its variants such as institutional repositories (IRs), is one of the most important changes in libraries triggered by advancements in ICT. DLs have caused fundamental changes in the way libraries operate. It has also challenged the traditional roles of libraries and compelled them to redefine their roles in this new environment. It is in this context that discussions in this chapter will proceed.

Discussions in this chapter are the results of the expansions and 'conversations' from several of my previous journal articles on IRs. However they will take into account as much as possible and where appropriate, recent developments and discussions about IRs. The discussions will also use Desa Informasi (Information Village) - an institutional repositories project at Petra Christian University (PCU) Library in Surabaya, Indonesia - as a study case. The project is not intended to serve as an example of a success in IRs implementation. In 
fact, it is still far from an ideal implementation of IRs. It is being used solely for the purpose of sharing experiences gained from its execution. Naturally, perspectives raised in the discussion will be of an academic librarian in a developing country. The environment, where the project is being carried out - a medium-sized private university with mostly undergraduate students - will certainly offers certain influences into the discussions as well.

\section{ICT Advancements and the future of libraries}

The rapid developments of ICT since the birth of computers and the Internet has contributed so much in changing the way we live our daily life. They affect the way we do things, which includes the way we do our jobs. They even affect the way we relate to one another in terms of personal relationships, as well as professional ones. Almost everything we do in daily basis has something to do with ICT. It ranges from simple stand-alone applications to collaborative and networked systems. Nowadays it's almost unimaginable to write an article without the help of a word processor application, online dictionary or thesaurus, reference management application, and online journal databases. All these advancements have offered invaluable help for people from any professions in terms of working more effectively and productively.

Some ICT advancements however can cause fundamental changes in the traditional roles and functions of certain professions. They fundamentally alter the ways in which people or institutions provide products and services. Libraries - especially academic libraries - and their librarians have been living through these inevitable, yet often subtle, transformations. Nowadays most librarians are familiar with - or at least aware of - approval plans, selector services, new acquisitions of library materials with embedded electronic bibliographic records, copy cataloging, self-check-in/out, Internet search engines, virtual reference services, etc. All these roles and/or functions (acquisition, cataloging, reference, etc.) were traditionally the domains of (local) librarians. Local librarians used to have the authority over or in charge of performing these roles and/or functions. However the new environment affected or created by ICT advancements has created new 'arrangements', where these basic roles and/or functions are gradually being taken over by ICT, or at least transferred to other institutions outside the libraries (Liauw, 2006b). In short, traditional roles and/or functions of librarians are being challenged by the rapid technological changes, which usually also leads to social changes.

Librarians need to 'redefine' their roles and/or functions in the new landscape of the future information society. Davenport stated something that I believe is a good response to the challenge. She suggested that librarians should have "expanded, more collaborative roles in the creation and dissemination of knowledge," which will empower (academic) libraries to assume new role and/or function as learning space instead of information storehouse (Davenport, 2006). It is now up to librarians on how to assume this 'new' role and/or function in the new landscape.

Digital libraries (DLs) and/or institutional repositories (IRs) offer opportunities for librarians and libraries to re-assert their influence in the creation and dissemination of knowledge. DLs/IRs is a strategic move for libraries to maintain their relevance in the new landscape of ICT-savvy society. However before going into any further discussions, we need to be on the same page on what we call digital libraries (DLs) and/or institutional repositories (IRs). 


\section{Institutional repositories and desa informasi}

IRs is one of the relatively new terms generated by advancements in ICT, one that needs to be defined to enable us to proceed with our discussion. One of the pioneers in IRs - Clifford Lynch - gave one of the most fundamental definitions of IRs:

"a university-based institutional repository is a set of services that a university offers to the members of its community for the management and dissemination of digital materials created by the institution and its community members. It is most essentially an organizational commitment to the stewardship of these digital materials, including long-term preservation where appropriate, as well as organization and access or distribution." (Lynch, 2003)

It is worth to mention specifically that Lynch defined IRs as "a set of services" instead of merely digital contents. Lynch also sees "institutional repositories as a species of digital library than a publishing platform," (Poynder, 2006) which is a sufficient ground for me to conclude that "the terms IRs and DLs ... [are] interchangeable" (Liauw, 2006a). Lynch's definition - "a set of services" - suggests his far reaching look into the future. However for the sake of flow of discussion, let's talk first about (digital) contents of IRs.

There are several different views on what IRs should contain. These different views don't necessarily contradict one another. They rather define IRs contents from different scopes and perspectives, which in my opinion can complement one another. McDowell gave a more technical classification of IRs contents by stating:

"IR contents were classified into the following types: ETDs; e-prints (pre- or post- print articles); working papers and technical reports; conference proceedings and presentations; $e$ journals and e-books; learning objects; multimedia files (digital audio/video); datasets; pictures (images); digitized archival documents and university records (historical texts and primary sources); non-scholarly institutional publications; undergraduate student work; graduate student work (non-ETD); and course content (syllabi, assignments, lectures)." (McDowell, 2007)

Crow defined IRs contents more concisely as "scholarly; produced, submitted, or sponsored by an institution's faculty (and, optionally, students), or other authorized agents; nonephemeral; and licensable in perpetuity" (Crow, 2002a). In terms of contents of IRs, Lynch suggested that:

"a mature and fully realized institutional repository will contain the intellectual works of faculty and students - both research and teaching materials - and also documentation of the activities of the institution itself in the form of records of events and performance and of the ongoing intellectual life of the institution." (Lynch, 2003)

It is interesting to notice that Lynch's definition above doesn't limit IRs contents to "the intellectual works of faculty and students - both research and teaching materials" (emphasis added) only. Instead it also encompasses "documentation of the activities of the institution itself in the form of records of events and performance and of the ongoing intellectual life of the institution" (emphasis added).

Desa Informasi (DI) adopts Lynch's definition for IRs contents and assumes that Crow's and McDowell's definitions as "subsets of Lynch's" (Liauw, 2006a) and summarizes them into the characteristic of "locally-produced" contents. Desa Informasi then expands the definition to also include contents that have "features of local entities" (Liauw, 2006b). Using parallel terminologies from the traditional (hardcopy) collections, the "locallyproduced" contents are the equivalence of "grey literature", while contents with "features of local entities" are the equivalence of "local collections" (see "Harrod's librarians' glossary and reference book"). The term "local content" is a familiar term among Indonesian 
librarians in defining both characteristics, and it will be used in this chapter to refer to contents with both characteristics.

DI started off as a limited-in-scope of theses digitization project to address the physical space limitation of PCU Library, which then evolved into an institutional repositories project. DI utilizes a custom-made web-based application called iSPEKTRA to manage digital objects using modified Dublin Core metadata set (http://dewey.petra.ac.id/dgt_directory.php). Although "interoperability on a metadata level has clearly been the most active area in digital repositories ... [and] spurred by the Open Access movement, numerous repositories exposed their metadata through standard protocols," (Aschenbrenner et al., 2008) iSPEKTRA has not yet addressed the interoperability issues in terms of compliance to Open Archives Initiatives - Protocol for Metadata Harvesting (OAI-PMH). It is a crucial issue that is being addressed along with the development of the new version of iSPEKTRA.

DI divides its collections into Themes instead of one big collection in order to create 'added value' to the collections. The main consideration is that "having several smaller thematic collections of interest to the communities is far better than having one big collection consisting of just about anything people can throw into the collection without any defining 'character' that binds them together" (Liauw, 2006a). The current DI collections are as follows: (Liauw, 2005)

- Digital Theses: Petra Christian University students' theses collection in digital format; mostly PDF documents. There are also an increasing number of multimedia resources generated by the students of Faculty of Art and Design.

- $\quad$ eDIMENSI: digital version of articles from DIMENSI, scientific journals published by various academic departments of Petra Christian University.

- Petra@rt Gallery: works of art by campus communities (mostly students' works) or works of art that are exhibited/displayed at Petra Christian University campus; mostly photographs and digitized-images. The collection contains wonderful visual resources, capturing and immortalizing the intrinsic knowledge and values of art in the works documented. Some of the wonderful themes are the Visual Poetry, Café Décor, Chairs of Indonesia, Destination Branded, Nusantara Bersatu (United Archipelago), etc.

- Petra iPoster: posters (with visual design elements) of events or issues related to Petra Christian University.

- Petra Chronicle: historical documents related to Petra Christian University.

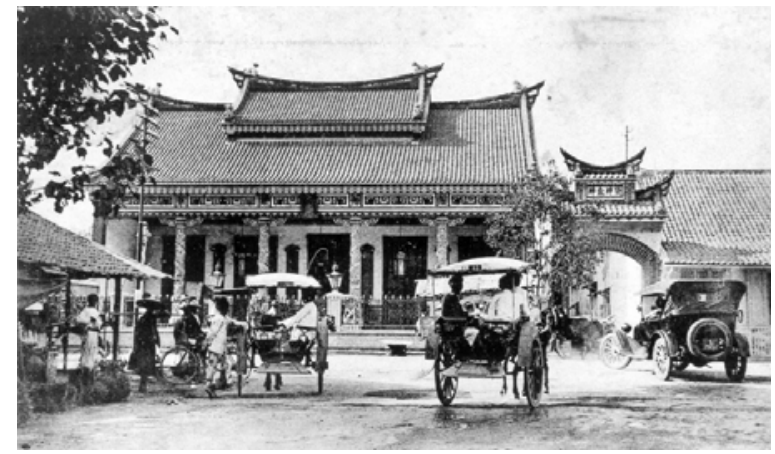

Fig. 1. An old photo from Surabaya Memory 
The collection themes above clearly represent the "locally-produced" definition of DI contents. One other collection that represents the definition of "features of local entities" is the Surabaya Memory collection. It contains digital heritage resources on Surabaya city. Another newly-planned collection will be the "Chinese in Indonesia" digital collection, which is intended to supplement the special collection of the same name (in physical/ hardcopy format). This latest collection (still in planning stage as of the time of this book's publication) is created as support system for the newly-established Center for Chinese Indonesian Studies at Petra Christian Universities.

\section{Facilitating structure amidst information overload and chaos}

As with most IRs, "student work accounts for the largest percentage of items" in DI. Digital Theses is the largest collection in DI so far. This phenomenon happens in many institutions implementing IRs since "ETDs [Electronic Theses and Dissertations] are simply the lowest hanging fruit, and new submission batches can generally be counted on each semester" (McDowell, 2007). ETDs are also the 'preferred' contents since they "raise the profiles of the students who author them, the faculty and departments who foster them, and the institutions that provide them to the world" (Lippincott, 2006). The following tables will give readers a glimpse of DI collections.

\begin{tabular}{|l|r|r|r|}
\hline Collection Name/Theme & \# of Records & \# of Digital Objects & Total Size (bytes) \\
\hline Digital Theses & 12,618 & 134,268 & $170,284,316,475$ \\
\hline eDIMENSI & 809 & 809 & $282,689,311$ \\
\hline Petra iPoster & 120 & 244 & 365.416 .831 \\
\hline Petra@rt Gallery & 261 & 854 & $4,132,526,401$ \\
\hline Surabaya Memory & 258 & 657 & $402,415,694$ \\
\hline Petra Chronicle & 180 & 559 & $2,489,567,862$ \\
\hline TOTAL & $\mathbf{1 4 , 2 4 6}$ & $\mathbf{1 3 7 , 3 9 1}$ & $\mathbf{1 7 7 , 9 5 6 , 9 3 2 , 5 7 4}$ \\
\hline
\end{tabular}

Table 1. Breakdown of Desa Informasi's Digital Collections by Themes (as of Aug 31, 2010). Source: Petra Christian University Library - 2009/2010 Annual Report

\begin{tabular}{|l|r|r|r|r|r|}
\hline \multirow{2}{*}{ Collection Name } & \multicolumn{7}{|c|}{ \# of Digital Objects } \\
\cline { 2 - 6 } & 115,830 & 18,228 & \multicolumn{1}{c|}{$\begin{array}{c}\text { Moving } \\
\text { Image/Video }\end{array}$} & $\begin{array}{c}\text { Animation } \\
\text { Audio, etc. }\end{array}$ & Auge \\
\hline Digital Theses & 809 & 0 & 0 & 24 & 07 \\
\hline eDIMENSI & 0 & 244 & 0 & 0 & 0 \\
\hline Petra iPoster & 57 & 797 & 0 & 0 & 0 \\
\hline Petra@rt Gallery & 25 & 632 & 0 & 0 & 0 \\
\hline $\begin{array}{l}\text { Surabaya } \\
\text { Memory }\end{array}$ & 160 & 399 & 0 & 0 & 0 \\
\hline Petra Chronicle & 116,881 & 20,300 & 119 & 24 & 67 \\
\hline TOTAL & & & & 0 & 0 \\
\hline
\end{tabular}

Table 2. Breakdown of Desa Informasi's Digital Collections by Types of Document (as of Aug 31, 2010). Source: Petra Christian University Library - 2009/2010 Annual Report 
In their article titled "Size isn't everything: Sustainable repositories as evidenced by sustainable deposit profiles," Carr \& Brody stipulated that "sustained deposits" is a more accurate measurement than merely the size of IRs, since it reflects "community engagement." They stated that "one of the measures of repository success should therefore be the university community's take-up of these services" (Carr \& Brody, 2007). They warned against using the size of IRs as the only indication of 'healthy' IRs. Referring to Davis and Connolly's 2007 article titled Institutional repositories: Evaluating the reasons for non-use of Cornell University's installation of DSpace, they noticed that "a repository can exhibit respectable overall growth that is attributable mainly to special-case batch imports" (Carr \& Brody, 2007). Along this line of thinking, we should then analyze the deposit profile of DI to see any indication of its 'health.' Table 3 shows the growth of digital resources in DI from 2005 up to 2010. Carr \& Brody used daily deposit profile in their survey of IRs by utilizing ROAR registry of Institutional Repositories. However since such data is not available for DI, Table 3 uses annual deposit profile instead.

\begin{tabular}{|l|r|r|r|r|r|}
\hline & $\mathbf{2 0 0 5 / 2 0 0 6}$ & $\mathbf{2 0 0 6 / 2 0 0 7}$ & $\mathbf{2 0 0 7 / 2 0 0 8}$ & $\mathbf{2 0 0 8 / 2 0 0 9}$ & \multicolumn{1}{|c|}{$\mathbf{2 0 0 9 / 2 0 1 0}$} \\
\hline \# of Records & 3,178 & 5,025 & 7,697 & 10,857 & 14,246 \\
\hline $\begin{array}{l}\text { Growth from Previous } \\
\text { Year }\end{array}$ & N/A & 1,847 & 2,672 & 3,160 & 3,389 \\
\hline \# of Digital Objects & N/A & 39,438 & 68,510 & 98,092 & 137,391 \\
\hline $\begin{array}{l}\text { Growth from Previous } \\
\text { Year }\end{array}$ & N/A & N/A & 29,072 & 29,582 & 39,299 \\
\hline
\end{tabular}

Table 3. Growth of Desa Informasi's Digital Collections (2005 - 2010).

Source: Petra Christian University Library - 2005/2006 to 2009/2010 Annual Reports

We can conclude from Table 3 that DI has a 'healthy' deposit profile since the growth of its contents is sustainable. Table 3 shows a steady growth in \# of Records and Digital Objects every year. It is an indication of community engagement in supplying resources for DI.

We can also conclude from our discussion so far that higher education institutions produced intellectual works in numerous subjects and formats besides the obvious scholarly works (theses and dissertations, journal articles, and research reports). Student works usually comprise the bulk of the works.

Unfortunately most lecturers and academic departments don't have the 'sensitivity' or the expertise needed to identify these student works as intellectual outputs that can be re-used as learning resources. They don't know how to collect, organize, manage, and re-use/serve these digital objects as learning resources. Davenport observed that "[academic departments in universities] lack the organization and structures that would allow campus departments to easily share such information" (Davenport, 2006). Based on my observations, most faculties only keep the digital version of the resources on CD Roms and stack them in cabinets. This practice will consequently make the resources hard to be found and re-used. It's as if faculties are lost amidst the chaotic and unstructured information overload.

Academic libraries could and should jump into the scene to introduce some sense of structure into the seemingly chaotic information resources produced by students (and faculties). IRs can be introduced as an elegant solution for the academic departments' need for organizing these works and re-use them as learning resources. JISC (Joint Information Systems Committee) suggested this approach when it reported that IRs "are increasingly expected to act as corporate information management tools (records management and 
content management systems) and data sharing platforms (e.g. for the re-use of research data and learning objects)" (Poynder, 2006). This is one of the variations of IRs implementations (Furlough, 2010) and a common approach in Indonesian higher education libraries. However libraries should not just offer the IRs platform as a solution and then leave the academic departments, faculties, and students on their own to figure out how to self-archive (uploading their works into the IRs) and help them organize those resources. Based on an article by Erickson, Rutherford, \& Elliott (2008), Salo warned against this approach when she reminded the readers that "the term 'self-archiving' has been taken too literal, abandoning faculty to their uncertainties and incapacities" (Salo, 2008).

Librarians should actively assume their 'new' role as IRs managers to increase the probability of a successful implementation of IRs by providing needed assistance to students and (especially) faculties in populating IRs. Libraries should do extra efforts to assist the academic departments, faculties, and students to get their works into IRs. However in their efforts to populate IRs, it is of a strategic importance for libraries to always present the issue as the academic departments and lecturers' interests, not merely the libraries' (Liauw, 2006a).

Mediated-deposit services was the method of choice for content acquisition for DI since it was formally launched in 2005. Local conditions required it and the fact that librarians would be the ones in charge of managing the contents - including the metadata - sounded more promising in the long run. The approach also asserts the role of librarians in providing some sense of structure into the whole collections. This choice turns out to be the right one since it works so far, while the alternative doesn't look too promising. In her article Salo stated that "the notion that faculty members [(and students for that matter)] will actually push buttons and type metadata in order to deposit materials into IRs is an article of faith among repository-software developers. In practice, however, most deposits are third-party mediated, many by librarians, some by support staff or IT personnel" (Salo, 2008, emphasis added). Salo's assertions and experience in DI prove that although mediated-deposit services might sound more 'expensive' and labor-intensive, it does offer more sustainability for IRs and more visibility to the role of librarians in the overall landscape of universitywide information management/organization.

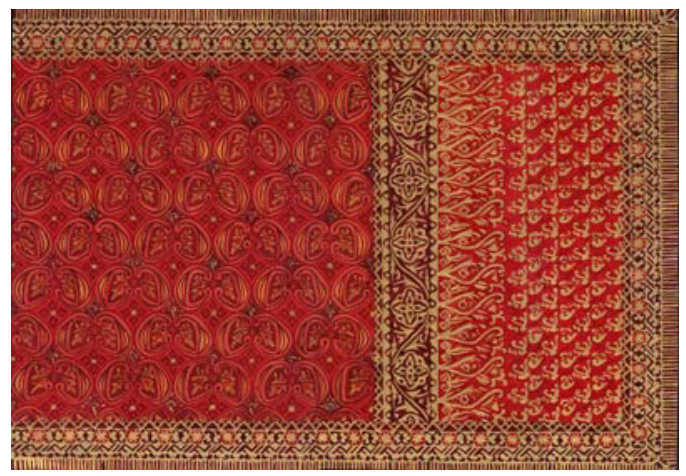

Fig. 2. Batik pattern in PetraArt Gallery

Content acquisition strategy is different from one collection to the others, based on the nature of the contents. For example, the content acquisition for Digital Theses is pretty 
straight forward since it 'piggybacks' on the university-wide theses deposit policy, which mandates all graduating students to deposit their theses to the Library in hardcopy and softcopy format. Contents for Petra@rt Gallery on the other hand are much harder to acquire since they are produced sporadically without any fixed-patterns. However it is crucial that content acquisition process establishes some kind of connections to the "administrative systems of the university or the local communities it serves" as Liauw suggested, since "otherwise the collection [(acquisition)] process will be too massive to manage sporadically and the sustainability of the flow of resources from the communities into the IRs will depend largely on fluctuating individual interests" (Liauw, 2006a). Contents for eDIMENSI are acquired through formal cooperation with the university's research center, which acts as the publisher for DIMENSI journals. This approach ensures 100\% incorporation of all articles published by the center into DI. Petra iPoster provides valuable lessons in its content acquisition effort and deserves a longer description. It is a common practice in Indonesian universities for the Public Relations office to be in charge for approving posters that will be posted on campus premises. We would have thought that a formal cooperation with the Public Relations office would guarantee $100 \%$ acquisition of posters at PCU by requiring poster-issuing units to provide the digital version of the submitted posters. However experience showed that it isn't as simple as that initial assumption. User behaviors play critical roles in this matter. Poster-issuing units usually don't have the digital version since they outsource the design and printing process to outside vendors. It requires extra time and effort to get them from the vendors. Other reasons might simply be the reluctance of the poster-issuing unit to spend more time preparing the digital copy to be submitted to the Public Relations office, especially when people are usually under a tight deadline to put the posters up. A request to provide an extra hardcopy poster as an alternative, instead of the digital version, was not successful either. We then noticed that another unit - the Campus Facility Management unit - is in charge for taking down 'expired' posters all across campus based on the expiry date stamped on each poster by the Public Relations office. We saw it as an opportunity to collect the posters for inclusion into Petra iPoster. So, instead of discarding the posters we merely ask the Campus Facility Management unit to send the posters to the Library. This never-thought-of-before approach proves to work well since it does not require any - or at least too much - disruption in the unit's daily operations. Aschenbrenner et al. suggested this approach by saying that "repositories [should] become a natural part of the user's daily work environment" (Aschenbrenner et al., 2008). The authors

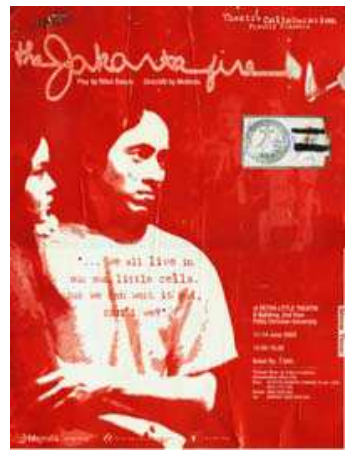

Fig. 3. Sample Poster from Petra iPoster 
were referring to the overall aspects of IRs but the principal can be applied in a narrower scope to content acquisitions in IRs. We don't encounter too many difficulties in acquiring contents for Petra Chronicle since most historical materials related to PCU will be deposited to the Library. The Library has had supports from various parties in developing Petra Chronicle and Petra iPoster since the personal nature of the resources, which have certain appeals to the nostalgic aspects of various stakeholders. The support only increases with the upcoming 50th Anniversary of PCU in 2011.

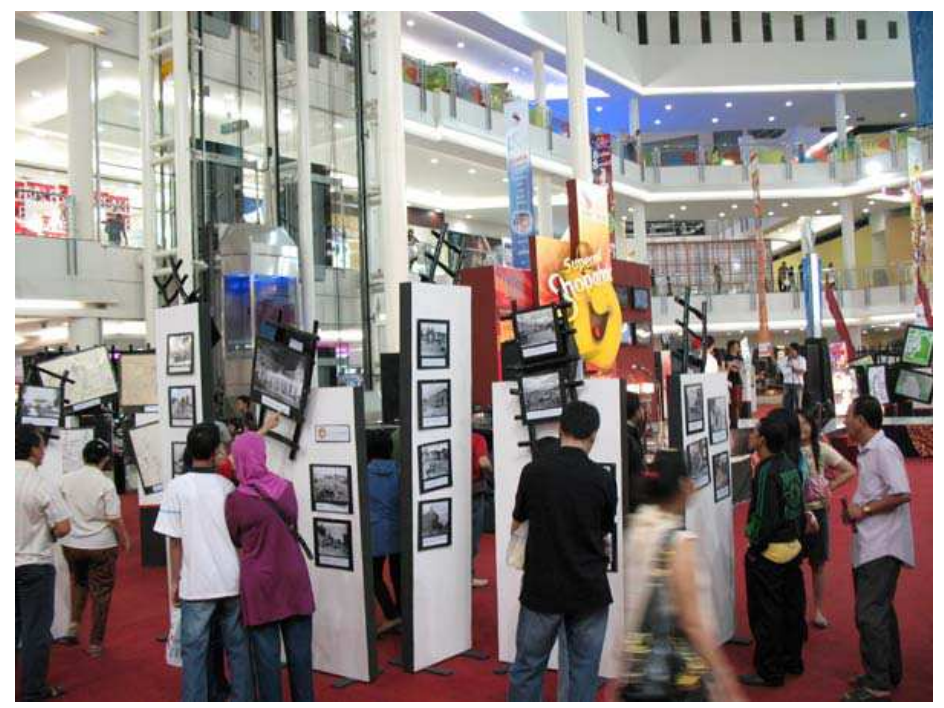

Fig. 4. Surabaya Memory Exhibition in A Mall (2007)

In acquiring contents for IRs, librarians should actively come to the academic departments, lecturers, and students as someone who is offering an information/resources management system to address their needs for organizing faculty and student works. IRs can be offered as the solution that will help in introducing and facilitating structure amidst the bulk and numerous different types of faculty and (especially) student works. Librarians will then be able to re-assert their role as information managers for their campus communities.

Surabaya Memory (SM) presents another challenge in its content acquisition due to the nature of its contents that features "local entities," which translates into public participation in the content development. Unlike contents for other collections in DI that are locally produced, contents for SM is developed by involving the campus communities as well as general public. There has been some level of public participation from individuals and organizations that lent their personal or institutional collections relating to the heritage and history of Surabaya city. However the current level of public participation is still not as well as expected. Liauw observed that the two main reasons for this lack of participation are "the lack of information-sharing culture and the sentimental/personal [or even financial] values of heritage-related resources to their owners or copyright holders." Bluntly put, "some people have been making money out of selling duplicates of old photographs and manuscripts" (Liauw, 2010). On the other side, some individuals have been spending a lot of money to acquire old photographs and manuscripts into their personal collections. The 
money spent in acquiring those resources has become a big obstacle to share the resources not even their digitized version - with the society. It's also a common knowledge that "big collectors tend to collect for their own enjoyment" (Liauw, 2010, emphasis added). Facing such challenges, Liauw suggested two strategies to help alleviate the problem. The first strategy is to collaborate with big collectors to hold exhibitions. When we have gained their trust it usually (but not always) is easier to solicit their participations by contributing some of their collections to SM. The second strategy is to "network with other heritage-based organizations to identify individuals with possession of cultural heritage materials" (Liauw, 2010). I would like to also add that it is very important to show to stakeholders (especially those big collectors) that the shared resources will benefit the society.

Although content acquisition itself has posed many challenges, it is essential that we do not view any IRs projects only as a matter of populating it with the desired contents. McDowell offered another perspective on IRs. He offered a definition from functional point of view, which defines IRs as: (McDowell, 2007)

1. "an institution-wide service. Faculty members of every academic unit must be able to submit, regardless of departmental affiliation [no use or subject limitations].

2. intended to collect, preserve, and provide access to, among other things, faculty scholarly output in multiple formats.

3. must be actively taking submissions."

Although DI does fulfill the above definition and has managed to reach some level of sustainability in content acquisition, it still falls short in providing services and interactions/ collaborations to its users, capitalizing on the acquired contents. Regarding future directions for IRs, Furlough suggested that IRs (contents) should be "integrated into instruction, reference and collection development" (Furlough, 2010).

Based on the discussions above IRs, such as DI, has managed to fulfill its role to "serve as tangible indicators of a university's quality and to demonstrate the scientific, societal, and economic relevance of its research activities." Let's now examine the successfulness of IRs in fulfilling its other role to "provide a critical component in reforming the system of scholarly communication ... [and to] reasserts control over scholarship by the academy, increases competition and reduces the monopoly power of journals" (Crow, 2002b).

\section{Facilitating scholarly communications}

Although reforming scholarly communication system has been one of the "two strategic issues" (Crow, 2002b) that IRs try to address, McDowell concluded that "IR has been relatively unsuccessful in fulfilling [that] 'original' role." This assertion was supported by his survey, which found that "the percentage of peer-reviewed works - pre- and post-prints, e-journal articles, and e-books - is considerably [small], around 13\%" (McDowell, 2007). It is obvious IRs has been facing serious challenges in the scholarly communication arena.

There are several reasons why IRs is not the preferred choice for disseminating researches. Aschenbrenner et al. observed that "journal publication patterns are already well in place and they are often (rightly or wrongly) considered the most reliable route to scientific credit" (Aschenbrenner et al., 2008). Foster added to that observation by identifying the current established system that "rewards faculty members with tenure and promotion based on their success at getting published in respected scholarly journals" as the main reason why "professors do not have much incentive to put their material in an experimental online archive" (Foster, 2004). There are also some faculties "who believe that self-archiving [in 
IRs] may threaten their rights over their work, their relationship with their favorite publishers, or their status in their disciplinary communities." This trend has led Salo to assert that "libraries whose support for repositories rests purely on hopes of collecting peerreviewed literature would be well-advised not to bother with them" (Salo, 2008).

Another challenge in the scholarly communication arena comes from the fact that most IRs are functioning only as digital resources management system, without "the more complex services on which users [authors or faculties] depend" (Chavez, et al., 2007). IRs might be useful and/or powerful for organizing and managing digital resources, but "[authors] want something that will support the authoring process, not just the finished product" (Foster, 2004). IRs also needs to strive to "become a natural part of the user's [or authors'] daily work environment" (Aschenbrenner et al., 2008). This might explain why IRs can achieve relative successes in acquiring contents from students, but not from faculties or peer-reviewed publication authors. Salo noticed that slight exceptions might apply for "younger scholars [or faculties, who] may [still] be attracted to self-archiving as a way to game a prestige system otherwise stacked against them" (Salo, 2008).

Besides all the shortcomings of IRs in the scholarly communication arena, I believe IRs has managed to reduce the total monopoly of conventional journal publishers. Many journal publishers have revised their publishing and copyright policies to allow authors to selfarchive in institutional or subject repositories. The new policies wouldn't have had materialized had it not been because of open access movement (or spirit) embodied in IRs. There are currently open access (book and journal) publishers offering alternatives to conventional publishers. More and more universities and research institutions are jumping into the open access (and IRs) bandwagon by instituting Open Access Mandates in their institutions. Although in its current state IRs might not achieve big success in (radically) reforming scholarly communication, I believe that IRs has contributed - to certain extent the efforts in "advancing the positive transformation of scholarly communication over the long term" (Crow, 2002b, emphasis added).

The same challenge is faced by DI in acquiring journal articles from faculties. DI - as an IRs system - has not yet accommodated any authoring or collaborative process. In its current state, DI acquires contents for eDIMENSI (scientific journal articles) collections through a formal cooperation with the Research Center at PCU. The Research Center is the formal agency at PCU that manages the review, editorial, and publication processes of DIMENSI journals using the Open Journal System (OJS). The cooperation allows the Library to batch download the newly published articles and feed them into DI. It might be the future direction to merge the two systems into a single platform, which will streamline much of the processes involved in both entities (Research Center and Library) and open up opportunities to create new collaborative features in the future.

\section{Facilitating collaborations}

An important aspect of IRs that is often overlooked is its potential as a collaborative platform for the campus communities. If we agree that IRs is, as Lynch stated, "a set of services that a university [library] offers to the members of its community for the management and dissemination of digital materials created by the institution and its community members" (Lynch, 2003, emphasis added) then academic libraries have an invaluable asset in their hands. This asset has a functions and/or roles that span traditional boundaries of campus communities, units, and academic disciplines. Due to this nature, 
academic libraries that implement and manage IRs will soon discover themselves introduced to a rich variety of local contents produced by different campus communities covering a wide range of academic disciplines.

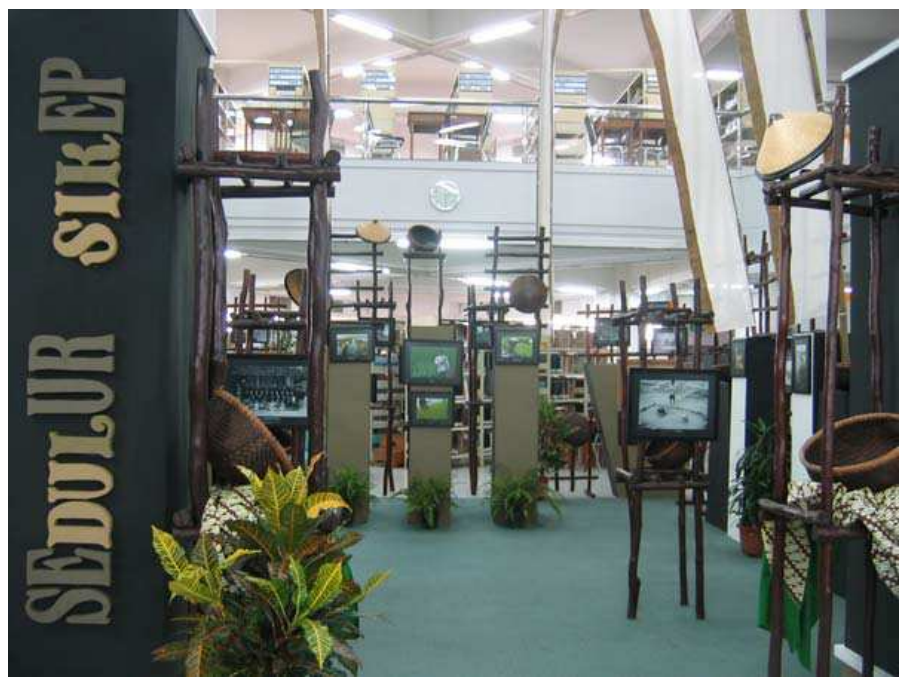

Fig. 5. A Thematic Onsite Exhibition Featuring Photography Documentary of Sedulur Sikep Ethnic Group in Central Java, Indonesia (2006)

Cross-pollination or cross-fertilization of knowledge is a natural consequence of exposures to such rich and diverse local contents. Contents produced by a campus community can be re-used as learning resources by other campus communities. Marketing or promotional efforts can be conducted by academic libraries to introduce these local contents to all academic departments and provide insights on possibilities of their uses for each department. Libraries can also expand features in their IRs to be able to link to e-learning systems (such as Moodle) used on campus. The linking will enable students and faculties to access our local contents directly from the e-learning systems that they are using for teaching and learning, thus increasing exposures of the contents to various campus communities. These efforts will expose local contents from a specific campus community to a wider audience.

Thematic exhibitions will also provide rich exposures for students, who otherwise would have been 'confined' to their particular field of studies. The experience will enrich students' learning experience. Thematic exhibitions of local contents can sometimes create unique opportunities for inter-disciplinary conversations. Liauw told of an interesting story as an example of how thematic exhibitions can create such conversations. A thematic onsite exhibition featuring photography documentary of Sedulur Sikep - an ethnic minority in Central Java, Indonesia - was held in 2006, displaying works of a student from Visual Communication Design Department. The exhibition sparked interests from other academic disciplines to conduct other researches on the ethnic minority. An English Department faculty was interested to conduct further study on the linguistic aspects of the ethnic minority. Another faculty from Interior Design Department expressed interests in doing further studies on the ornamental design on the ethnic's settlements (Liauw, 2006b). This 
example shows that academic libraries should treat their local contents and exhibition spaces as assets to be used to facilitate collaborations and conversations across academic disciplines.

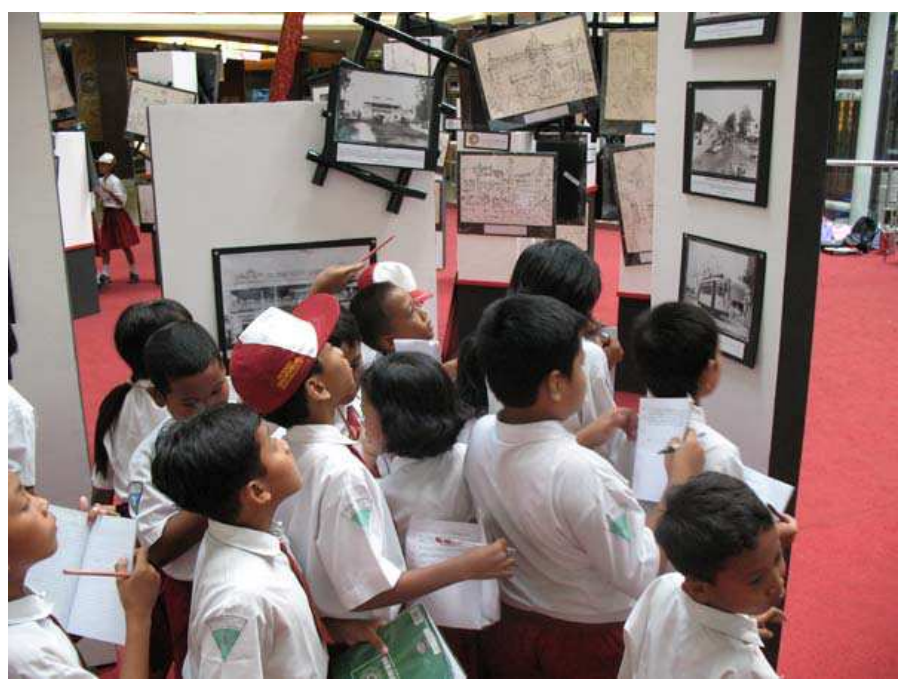

Fig. 6. School Children Playing Information Scavenger Game at Surabaya Memory Exhibition (2007)

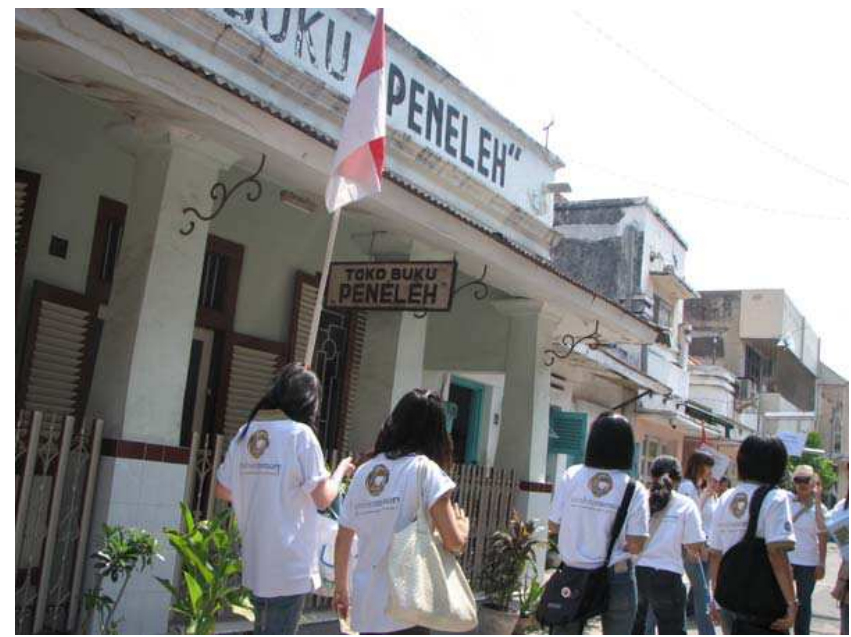

Fig. 7. Surabaya Memory Heritage Walk (2007)

Wider collaborations among different campus units and academic departments can be facilitated when academic libraries capitalize on their local contents in IRs to reach out to the society. Academic libraries can create and carry out various programs and activities jointly with other campus communities. Surabaya Memory (SM) provided a good example on this aspect. Digital resources in SM have been used as part of the teaching and learning process 
by Architecture Department, Tourism and Leisure Management Department, and Hotel Management Department. However SM has also become a collaborative platform for PCU Library and other campus units to reach out to the society in Surabaya city. Every May (anniversary of Surabaya) SM conducts thematic exhibitions in a mall in Surabaya. During the exhibition, which usually lasts four to ten days, various competitions, cultural performances, and heritage walks are held to celebrate the city's anniversary. All these programs and activities have been made possible by the collaborations between the Library and various academic departments. The Event Management course at Hotel Management Department has been using SM as real world projects for its students. The students are assigned to help the Library in preparing and supervising the exhibition, looking for sponsors, creating events and performances during the exhibition, etc. The Cultural Tourism course at Tourism and Leisure Management Department has also been using SM as real world projects for its students by conducting heritage walks throughout the year for campus communities as well as the general public. IRs can also serve as collaborative platform to build networks with various parties outside the university boundaries. SM has been functioning as a networking tool for PCU. Various co-operations and collaborations have been initiated between PCU communities and outside parties through SM. Furthermore SM has served as a common platform for campus communities at PCU to reach out to the society.

It is obvious from the discussions above that IRs can facilitate collaborations if academic libraries are willing to go beyond merely populating their IRs with digital contents. Collaborations with various campus communities will strengthen the libraries' roles on campus and help libraries tremendously in advocating their services to the campus communities. Libraries can even increase the institutional visibility of the whole institution with their IRs projects.

\section{Facilitating institutional visibility}

Academic libraries have always contributed to the institutional visibility of their host institutions. They have unconsciously played 'silent' marketing role, promoting their host institutions in the process. Their unique nature as public spaces has allowed them to be visited by various members of the community, inside and outside of campus boundaries. Libraries are the very few institutions in the world where ordinary people would feel comfortable to visit even though they don't have any membership or institutional affiliation. Academic libraries should capitalize on this aspect to facilitate institutional visibility. Before the advent of the Internet and DLs/IRs, this would mean providing their traditional collections and services, and physical spaces to the campus communities and the society.

The Internet, open access movement, and DLs/IRs have provided new opportunities for academic libraries to raise their contributions to the facilitating of institutional visibility of their host institutions. Digital contents in IRs should be provided freely to enable a wider dissemination to the global audience, which in turn will translate into a significant increase in institutional visibility. There is no longer any physical barrier that limits the scope of the dissemination of the IRs' contents as in physical library collections. This is also the experience of DI. Table 4 shows the web access profile for "petra.ac.id" domain (accessed on September 30, 2010 from http://www.alexa.com). The table shows that http://digilib.petra.ac.id (the server that stores the digital local content of DI) and 
Where Visitors Go on Petra.ac.id

\begin{tabular}{lr} 
Subdomain & Percent of Site Traffic \\
\hline digilib.petra.ac.id & $59.6 \%$ \\
\hline dewey.petra.ac.id & $20.5 \%$ \\
\hline petra.ac.id & $5.1 \%$ \\
\hline genesis.petra.ac.id & $4.3 \%$ \\
\hline careercenter.petra.ac.id & $4.3 \%$ \\
\hline puslit2.petra.ac.id & $1.8 \%$ \\
\hline faculty.petra.ac.id & $1.1 \%$ \\
\hline fportfolio.petra.ac.id & $1.1 \%$ \\
\hline it.petra.ac.id & $0.7 \%$ \\
\hline puslit.petra.ac.id & $0.7 \%$ \\
\hline communication.petra. ac.id & $0.4 \%$ \\
\hline john.petra.ac.id & $0.4 \%$
\end{tabular}

Table 4. Domain Profile for "petra.ac.id" from Alexa Source: http:/ / www.alexa.com/siteinfo/petra.ac.id

http://dewey.petra.ac.id (the online catalog of PCU Library that store the metadata of the digital resources stored in DI) are the two top sub-domains that generate $80.1 \%$ of the traffic to "petra.ac.id" domain. (years) age range and mostly browse the Internet from school or home. This is a very significant contribution that PCU Library - through DI - has made to the overall 'Internet marketing' of the university. The access statistics from Alexa is confirmed by the weblog of the DI server (http://digilib.petra.ac.id) as shown in Table 5.

More opportunities to facilitate institutional visibility can be gained when we share metadata of our digital contents with other IRs. This can be achieved by utilizing the OAI$\mathrm{PMH}$ or even a 'low-tech' approach by exporting the metadata and exchange them using spreadsheet application such as Microsoft Excel. This approach is being utilized by DI while an upgrade to an OAI-PMH compliant system is still in progress. The Indonesian Ministry of National Education under its Directorate General of Higher Education has launched a collaborative program to create a 'union catalog' of metadata for local contents from higher education institutions across Indonesia called Garuda (http://garuda.dikti.go.id). Networking opportunities like this provide increased visibility of our IRs and host institution.

Rankings by independent organizations that measure websites and online resources provide additional incentives for developing IRs. One of them is the Ranking Web of World Universities (http://www.webometrics.info) that measures world universities' commitment to open access by looking at digital contents on their websites. Using certain methodology it has managed to rank world universities based on several parameters. DI opens up its digital contents to be indexed by Google, which has enabled Webometrics to measure the "Size" and "Rich Files" (see http://www.webometrics.info/methodology.html) stored in DI. 


\begin{tabular}{|r|r|r|r|r|r|}
\hline \multicolumn{1}{|c|}{ Month } & \multicolumn{1}{c|}{$\begin{array}{c}\text { Unique } \\
\text { Visitors }\end{array}$} & $\begin{array}{c}\text { Number of } \\
\text { Visits }\end{array}$ & \multicolumn{1}{c|}{ Pages } & \multicolumn{1}{c|}{ Hits } & \multicolumn{1}{c|}{ Bandwidth } \\
\hline Sep-09 & 160,097 & 355,177 & $3,125,802$ & $6,686,167$ & $191.36 \mathrm{~GB}$ \\
\hline Oct 2009 & 224,082 & 607,877 & $5,305,997$ & $11,296,525$ & $315.91 \mathrm{~GB}$ \\
\hline Nov 2009 & 215,583 & 563,184 & $5,005,537$ & $10,664,877$ & $325.83 \mathrm{~GB}$ \\
\hline Dec 2009 & 201,370 & 510,646 & $4,581,746$ & $9,751,878$ & $283.93 \mathrm{~GB}$ \\
\hline Jan-10 & 212,415 & 538,796 & $4,538,643$ & $9,769,348$ & $295.05 \mathrm{~GB}$ \\
\hline Feb-10 & 197,727 & 450,327 & $4,293,240$ & $8,789,435$ & $360.64 \mathrm{~GB}$ \\
\hline Mar-10 & 247,483 & 615,001 & $5,058,876$ & $10,573,688$ & $431.89 \mathrm{~GB}$ \\
\hline Apr-10 & 237,076 & 577,638 & $4,845,910$ & $10,138,585$ & $454.83 \mathrm{~GB}$ \\
\hline May 2010 & 207,424 & 484,272 & $4,225,088$ & $8,831,741$ & $436.39 \mathrm{~GB}$ \\
\hline Jun-10 & 199,156 & 454,782 & $3,975,456$ & $8,281,444$ & $496.72 \mathrm{~GB}$ \\
\hline Jul-10 & 174,474 & 360,614 & $3,175,481$ & $6,503,735$ & $398.71 \mathrm{~GB}$ \\
\hline Aug 2010 & 157,810 & 317,685 & $2,804,185$ & $5,897,145$ & $338.25 \mathrm{~GB}$ \\
\hline & $2,434,697$ & $5,835,999$ & $50,935,961$ & $107,184,568$ & $4,329,51 \mathrm{~GB}$ \\
\hline
\end{tabular}

Table 5. Web Access Statistics of Desa Informasi (Sep 2009 - Aug 2010)

Source: http://digilib.petra.ac.id/awstats/awstats.pl

Webometrics rankings are important for us in Indonesia since they are being used by Directorate General of Higher Education as one of several metrics to measure performances of Indonesian higher education institutions. PCU has been ranked \#5 along with big state universities in Indonesia. A good rank will surely contribute to the increased visibility of the host institutions. This fact strengthens the assertion that IRs serve as one of "meaningful indicators of an institution's academic quality ... thus increasing the institution's visibility, status, and public value" (Crow, 2002b).

\section{Conclusion}

Advancement in ICT has reshaped the landscape of the future for many professions. Librarian as a profession and libraries as institutions are not immune to changes brought by ICT. Many of their traditional functions and/or roles have been altered or even taken away from them by technology, thus librarians and libraries -especially academic libraries - need to 'redefine' their functions and/or roles to stay relevant in the new landscape of the future. Institutional repositories (IRs) - as a species of digital libraries (DLs) - provides opportunities for academic libraries to re-assert their roles in the communities they serve. Through IRs academic libraries can strengthen their roles as managers of institutional information assets and re-use them as learning resources for the benefits of the campus communities.

In their efforts to populate IRs, academic libraries should not leave faculties on their own. Besides providing an IRs application to manage digital contents, libraries should also assist faculties and campus communities in identifying, collecting, and re-using those contents. By 
doing all these efforts libraries introduce structure into the myriads of digital contents available in or produced by campus communities.

Although in the scholarly communications arena IRs has not yet achieved substantial successes, IRs has managed to at least reduce the total domination of conventional journal publishers. With extra efforts libraries can utilize IRs to facilitate scholarly 'conversations' across different academic disciplines on campus.

By setting goals beyond merely populating IRs, libraries will be able to capitalize on IRs' contents to create various programs and activities that will facilitate and foster collaborations among different campus communities, and between campus communities and the society. IRs can even develop into a common platform for campus communities to reach out to the society.

Amidst the ups and downs of IRs projects in academic libraries across the globe I would like to echo the optimism voiced by Aschenbrenner et al.:

"Digital repositories have rapidly become an integral part of higher education and other digital environments. Setbacks with regard to user adoption, and technological dead ends of insular efforts, have not induced a significant dip in the growth of the community. Instead, they have added new perspectives on how repositories can be embedded into their organizational and social contexts." (Aschenbrenner et al., 2008)

More fundamentally, amidst technological changes and the changing landscape of our profession, I would like to close our discussion by citing one of the fundamental principles of our profession:

Underlying the special character of librarianship is not its techniques, but its fundamental values. The significance of librarianship lies not in mastery of sources, organizational skills, or technological competence, but in why librarians perform the functions they do. (Rubin, 2004, p. 468)

\section{References}

Aschenbrenner, Andreas et al. (2008). The future of repositories? Patterns for (cross-) repository architectures. D-Lib Magazine, 14 (11/12), November/December 2008. Retrieved September 03, 2010 from

http://www.dlib.org/dlib/november08/aschenbrenner/11aschenbrenner.html

Carr, Leslie \& Brody, Tim. (2007). Size isn't everything: Sustainable repositories as evidenced by sustainable deposit profiles. D-Lib Magazine, 13 (7/8), July/August 2007. Retrieved September 03, 2010 from

http:/ / www.dlib.org/dlib/july07/carr/07carr.html

Chavez, Robert et al. (2007). Services make the repository. Journal of Digital Information, 8(2). Retrieved on September 03, 2010 from http://journals.tdl.org/jodi/article/view/195/179

Crow, Raym. (2002a). SPARC institutional repository checklist E resource guide. Washington, D.C.: The Scholarly Publishing \& Academic Resources Coalition. Retrieved September 03, 2010, from

http://www.arl.org/sparc/bm doc/IR_Guide_\&_Checklist_v1.pdf

Crow, Raym. (2002b) The Case for Institutional Repositories: A SPARC Position Paper. Washington, D.C. The Scholarly Publishing \& Academic Resources Coalition. Retrieved September 03, 2010 from

http:// www.arl.org/sparc/bm doc/ir_final_release_102.pdf 
Davenport, Nancy. (2006). Place as Library? EDUCAUSE, January/February 2006. Retrieved September 03, 2010, from http:// www.educause.edu/ir/library/pdf/erm0616.pdf

Erickson, J., Rutherford, J., \& Elliott, D. (2008) The future of the institutional repository: Making it personal. In Third International Conference on Open Repositories 2008. Retrieved April 10, 2008, from http:// pubs.or08.ecs.soton.ac.uk/125/

Foster, Andrea L. (2004). Papers wanted: Online Archives Run by Universities Struggle to Attract Material. Chronicle of Higher Education, 50 (42), pp. A37-A38.

Furlough, Michael. (2010). Sepulchres. Personal blog. Retrieved September 03, 2010, from http://www.personal.psu.edu/mjf25/blogs/on_furlough/2010/05/sepulchres.ht $\mathrm{ml}$

Liauw, Toong Tjiek. (2005). Desa Informasi: Local Content Global Reach. Proceeding of the 2005 Seminar of the International Council on Archives, Section on University and Research Institution Archives. Michigan State University, East Lansing, MI - U.S.A. (Sep 6-9, 2005).

Liauw, Toong Tjiek. (2006a). Desa Informasi - The Role of Digital Libraries in the Preservation and Dissemination of Indigenous Knowledge. International Information and Library Review, 38(3), pp. 123-131.

Liauw, Toong Tjiek. (2006b). Desa Informasi: A virtual village of 'new' information resources and services. Program: Electronic Library and Information System, 41 (3), pp. 276-290.

Liauw, Toong Tjiek. (2010). Surabaya Memory: Opportunities and challenges of open access e-heritage repositories. In IFLA Satellite Pre-conference. Mediterranean Agronomic Institute of Chania, Crete - Greece (Aug 6-8, 2010).

Lippincott, Joan K. (2006). Institutional Strategies and Policies for Electronic Theses and Dissertations. EDUCAUSE Center for Applied Research, 2006(13). Retrieved Septermber 03, 2010 from

http://www.educause.edu/ir/library/pdf/ERB0613.pdf.

Lynch, Clifford A. (2003). Institutional Repositories: Essential Infrastructure for Scholarship in the Digital Age. ARL Bimonthly Report, 226. Mar 26, 2004. Retrieved September 03, 2010 from http:// www.arl.org/bm doc/br226ir.pdf

McDowell, C. (2007). Evaluating institutional repository deployment in American academe since early 2005: Repositories by the numbers, part 2. D-Lib Magazine, 13(9/10). Retrieved September 03, 2010, from http://www.dlib.org/dlib/september07/mcdowell/09mcdowell.html

Poynder, Richard. (2006). Clear Blue Water. September 03, 2010. http:/ / dialspace.dial.pipex.com/town/parade/df04/BlueWaterMain.pdf

Rubin, Richard E. (2004). Foundations of Library and Information Science (2nd Editiion). New York: N.Y.

Salo, Dorothea. (2008). Innkeeper at the Roach Motel. Library Trends. University of Illinois at Urbana-Champaign. Retrieved September 03, 2010 from HighBeam Research: http://www.highbeam.com/doc/1P3-1661837451.html 


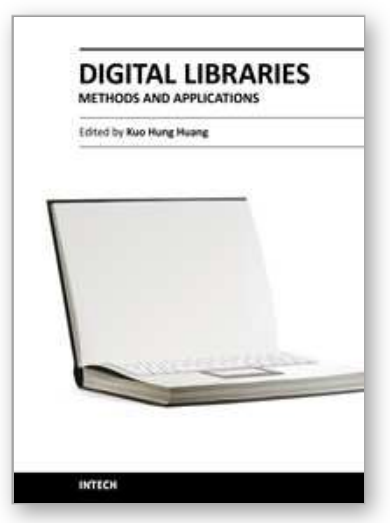

\author{
Digital Libraries - Methods and Applications \\ Edited by Dr. Kuo Hung Huang
}

ISBN 978-953-307-203-6

Hard cover, 220 pages

Publisher InTech

Published online 04, April, 2011

Published in print edition April, 2011

Digital library is commonly seen as a type of information retrieval system which stores and accesses digital content remotely via computer networks. However, the vision of digital libraries is not limited to technology or management, but user experience. This book is an attempt to share the practical experiences of solutions to the operation of digital libraries. To indicate interdisciplinary routes towards successful applications, the chapters in this book explore the implication of digital libraries from the perspectives of design, operation, and promotion. Without common agreement on a broadly accepted model of digital libraries, authors from diverse fields seek to develop theories and empirical investigations that to advance our understanding of digital libraries.

\title{
How to reference
}

In order to correctly reference this scholarly work, feel free to copy and paste the following:

Liauw Toong Tjiek (Aditya Nugraha) (2011). Institutional Repositories: Facilitating Structure, Collaborations, Scholarly Communications, and Institutional Visibility, Digital Libraries - Methods and Applications, Dr. Kuo Hung Huang (Ed.), ISBN: 978-953-307-203-6, InTech, Available from:

http://www.intechopen.com/books/digital-libraries-methods-and-applications/institutional-repositoriesfacilitating-structure-collaborations-scholarly-communications-and-instit

\section{INTECH}

open science | open minds

\author{
InTech Europe \\ University Campus STeP Ri \\ Slavka Krautzeka 83/A \\ 51000 Rijeka, Croatia \\ Phone: +385 (51) 770447 \\ Fax: +385 (51) 686166 \\ www.intechopen.com
}

\author{
InTech China \\ Unit 405, Office Block, Hotel Equatorial Shanghai \\ No.65, Yan An Road (West), Shanghai, 200040, China \\ 中国上海市延安西路65号上海国际贵都大饭店办公楼 405 单元 \\ Phone: +86-21-62489820 \\ Fax: +86-21-62489821
}


(C) 2011 The Author(s). Licensee IntechOpen. This chapter is distributed under the terms of the Creative Commons Attribution-NonCommercialShareAlike-3.0 License, which permits use, distribution and reproduction for non-commercial purposes, provided the original is properly cited and derivative works building on this content are distributed under the same license. 